Original Research Article

\title{
A study on the safety and tolerability of mycophenolate mofetil in patients with connective tissue disease
}

\author{
Subham Das ${ }^{1}$, Prasanta Padhan ${ }^{2 *}$
}

${ }^{1}$ Department of Pharmacology, GIMSH, Durgapur, West

Bengal, India

${ }^{2}$ Department of Rheumatology, KIMS, Bhuvneshwar, Odisha, India

Received: 20 August 2018 Accepted: 27 September 2018

\section{*Correspondence to: \\ Dr. Prasanta Padhan, \\ Email: prasanta.padhan@ gmail.com}

Copyright: (C) the author(s), publisher and licensee Medip Academy. This is an openaccess article distributed under the terms of the Creative Commons Attribution NonCommercial License, which permits unrestricted noncommercial use, distribution, and reproduction in any medium, provided the original work is properly cited.

\begin{abstract}
Background: Connective tissue disorders (CTD) are mostly due to inflammatory and fibrotic tissue injury. Glucocorticoids and immunomodulators though useful but are toxic. Mycophenolate mofetil (MMF) is now being used successfully in many autoimmune diseases, but the safety of MMF in CTD patients is yet to be conclusively established.

Methods: The study was a retrospective record based observational one in patients of CTD satisfying the predetermined inclusion criteria. Various safety parameters were noted down from the observed records and analysed accordingly.

Results: The 120 case records of CTD patients were analysed for a specific set of safety parameters over the preceding one year. Diarrhoeal attacks were the most commonly encountered side effect $(38.3 \%)$ of long term patients who were on mycophenolate therapy followed by infection.

Conclusions: Mycophenolate was found to be generally well tolerated in CTD patients with few reports of adverse events, but larger clinical trials are needed to conclusively establish its safety.
\end{abstract}

Keywords: Autoimmune disease, Connective tissue disorders, CTD, Immunomodulators, Mycophenolate mofetil

\section{INTRODUCTION}

The connective tissue diseases (CTD) are a group of disorders due to inflammatory and fibrotic tissue injury. Although glucocorticoids remain the mainstay of treatment options for CTD, certain immunomodulatory agents like azathioprine have also become a part of treatment plan.

Both glucocorticoids and immunomodulators like azathioprine however come with their own potential toxicities and side effects to the patients of CTD. Of late, mycophenolate mofetil (MMF), which acts on purine

\begin{abstract}
biosynthesis pathway and thereby halting lymphocyte proliferation, has been successfully used to treat patients with several connective tissue diseases as well as other autoimmune diseases like rheumatoid arthritis, lupus nephritis, Sjögren's syndrome, Wegener's granulomatosis etc. ${ }^{1-4}$ In spite of having many studies that established the efficacy of mycophenolate in many other conditions, considering the paucity of studies involving use of mycophenolate in CTD patients, authors have conducted this study. ${ }^{5,6}$ The objective of this study was to evaluate the safety and tolerability of mycophenolate mofetil in a heterogeneous group of patients with various connective tissue diseases.
\end{abstract}




\section{METHODS}

This study was a record based retrospective observational study. Authors have collected the case history and treatment sheets of all the patients having a diagnosis of CTD and prescribed mycophenolate mofetil for the preceding one year. Only those patients who had taken the medicine for at least six months and had presented for at least one follow-up were included in the study. Authors have reviewed complete medical records of the included subjects and noted down the demographics, duration of treatment with mycophenolate, treatment related side effects and dose and frequency of co-administered glucocorticoids if that have been used. In case of any query the respective patient or relatives were contacted over telephone and data were verified telephonically. Since it was a retrospective record-based study no ethical clearance was required. However, the privacy and confidentiality of all the patient related information was maintained throughout the duration of the study. We collected the data from the medical records section as well as from the rheumatology OPD of all the potential patients from July 2015 until July 2016. Data regarding safety and tolerability of mycophenolate mofetil that were noted down are number of times of diarrhoea attacks, number of times of general infectious diseases, total number of hospitalisations (if any), number of herpes zoster infections; all the information were observed for the preceding one year. Additional data that were noted are average duration of mycophenolate therapy and average dose of glucocorticoid therapy in each patient. The analysis and graphical representation were done using Microsoft Excel.

\section{RESULTS}

In this study the treatment records of total 120 patients were analysed who were being treated with MMF. The duration of MMF usage in all the patients were between 6 months to 4 years. 17 patients out of them were male and rest 103 were female patients. 7 patients out of total 120 were not under any steroid medication. Among the other 113 patients, most of them were on oral steroids under tablet dexamethasone $5 \mathrm{mg}$ once daily or alternate day or equivalent doses of deflazacort. The various doses of MMF used in various patients are listed in table 1.

Table 1: Different doses of MMF / mycophenolic acid usage as per number of patients.

\begin{tabular}{|ll|}
\hline $\begin{array}{l}\text { Dose of Mycophenolic acid / } \\
\text { Mycophenolate mofetil (MMF) }\end{array}$ & $\begin{array}{l}\text { Number of } \\
\text { patients }\end{array}$ \\
\hline 360mg & 56 \\
\hline $540 \mathrm{mg}$ & 38 \\
\hline $180 \mathrm{mg}$ & 2 \\
\hline $500 \mathrm{mg}(\mathrm{MMF})$ & 17 \\
\hline $750 \mathrm{mg}(\mathrm{MMF})$ & 7 \\
\hline Total & 120 \\
\hline
\end{tabular}

The common safety issues associated with the use of MMF that were looked for in the treatment records were number of diarrhoeal attacks, number of other infectious diseases, number of herpes zoster infections, total encounters of hospital admissions, cytopenias and malignancies (table 2). Out of all the 120 case-records, total 34 patients had an episode of diarrhoea at least once during the preceding one year. 12 cases were found where there were incidences of two diarrhoeal attacks in the last once year. 16 cases out of total 120 case records had at least another infection recorded during the last one year, sites of infection being respiratory tract $(n=11)$, urinary tract $(n=3)$, and site was not specified for 2 cases. Two cases were found among these 16 patients who had some infectious disease more than once and both of them were under mycophenolate for the last three years. Only six patients out of these 120 cases had to get admitted in the hospital due to any medical illness. Two cases out of these 120 patients had occurrence of cytopenia in the form of anaemia within the preceding one year. None of the records that were observed by us had any mention of herpes zoster infection or any malignancy in the preceding one year. Most of the patients were on some additional oral steroids. Out of total 113 such patients on additional oral steroids, 37 were on dexamethasone $5 \mathrm{mg}$ daily, 35 were on $5 \mathrm{mg}$ alternate day, rest were on low doses of tab deflazacort.

Table 2: Adverse events in mycophenolate treated patients within last one year.

\begin{tabular}{|ll|l|}
\hline $\begin{array}{l}\text { Possible adverse } \\
\text { events due to } \\
\text { mycophenolate }\end{array}$ & $\begin{array}{l}\text { Number of } \\
\text { patients }\end{array}$ & $\begin{array}{l}\text { Percentage of } \\
\text { total patients } \\
\mathbf{n = 1 2 0}\end{array}$ \\
\hline $\begin{array}{l}\text { Diarrhoeal attacks } \\
\text { Herpes Zoster }\end{array}$ & 46 & $38.3 \%$ \\
\hline infection & 0 & -- \\
\hline Any other infection & 16 & $13.3 \%$ \\
\hline Hospital admission & 6 & $5 \%$ \\
\hline Cytopenias & 2 & $1.6 \%$ \\
\hline Malignancies & 0 & -- \\
\hline
\end{tabular}

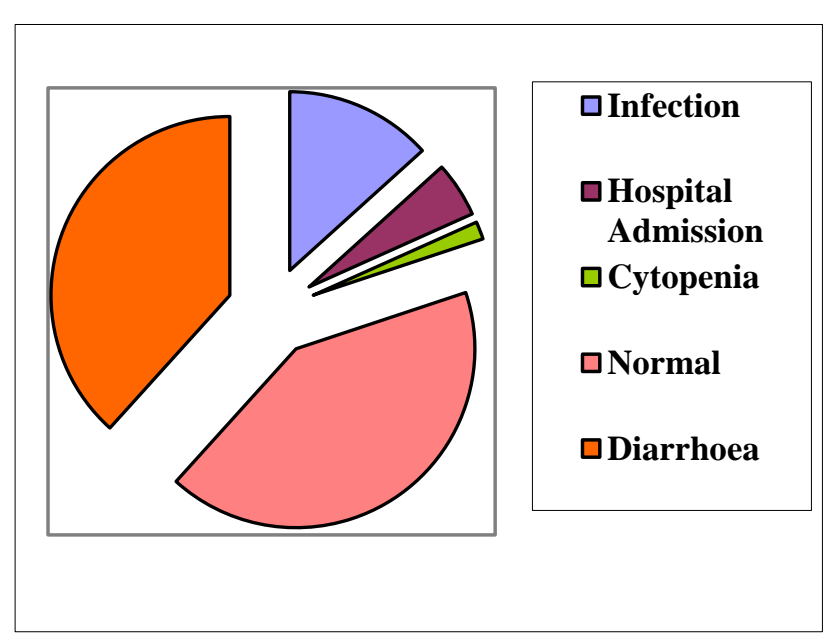

Figure 1: Incidence of adverse events in mycophenolate treated patients. 


\section{DISCUSSION}

The current study suggests that diarrhoeal attacks were the most commonly encountered adverse events reported in patients on long term mycophenolate therapy. Despite about $38 \%$ of reported adverse events being diarrhoeal attacks, mycophenolate still was a fairly tolerated treatment strategy with very low hospital admission rate. The causal factor behind the gastrointestinal events might be because of the effect on enterocytes dependent on the purine synthesis pathway blocked by the pharmacological action of mycophenolate. ${ }^{7}$ Due to that, mucosal erythema, hypersecretion of fluids, intestinal ulcerations occur. However, the reporting of diarrhoeal attacks was subjective in most cases, and diarrhoeal attack itself is a fairly common complaint in this part of the world. Had there been any objective method like that of the UCLA Scleroderma Clinical Trial Consortium Gastrointestinal Tract Instrument (UCLA-SCTC GIT) that is efficient at assessing the GI tract, the particular effect of mycophenolate on GI tract could be more specifically established. ${ }^{8}$

In the current study, the rate of infection was definitely lower than that reported in other clinical trials involving mycophenolate mofetil and mycophenolic acid..$^{-11}$

Hospital admissions due to any cause during the course of mycophenolate therapy was also found to be quite low in the current study which is also evident in other reported studies done by Mendoza et al, Derk et al, etc. ${ }^{12,13}$

Overall the tolerability of mycophenolate was found to be good in this study in contrast to that done by Stratton et al, where as many as $43 \%$ of patients had developed some adverse effects of mycophenolate. ${ }^{14}$

Authors have acknowledged the possible limitations of our study that include the variability in the mycophenolate dose used, heterogeneity of the cases taken with regard to demography, disease duration, use of different doses of steroids etc which are all the disadvantages of a retrospective medical record-based observational study.

\section{CONCLUSION}

Mycophenolate as a treatment option appears to be well tolerated although gastrointestinal adverse effects in the form of diarrhoeal attacks, infectious diseases and cytopenia in very few cases remain a point of concern regarding the safety issues associated with the drug. However, taking in consideration the various limitations of this retrospective observational study, further randomised safety clinical trials may be undertaken to confirm these findings.

\section{Funding: No funding sources Conflict of interest: None declared Ethical approval: Not required}

\section{REFERENCES}

1. Allison AC, Eugui EM. Immunosuppressive and other effects of mycophenolic acid and an ester prodrug, mycophenolate mofetil. Immunol Rev. 1993;136:528.

2. Das S, Padhan P. An overview of the extraarticular involvement in rheumatoid arthritis and its management. J Pharmacol Pharmacother. 2017;8:816.

3. Chan TM, Li FK, Tang CS, Wong RW, Fang GX, Ji $\mathrm{YL}$, et al. Efficacy of mycophenolate mofetil in patients with diffuse proliferative lupus nephritis. New England J Med. 2000 Oct 19;343(16):1156-62.

4. Nowack R, Göbel U, Klooker P, Hergesell O, Andrassy K, Van Der Woude FJ. Mycophenolate Mofetil for Maintenance Therapy of Wegener's granulomatosis and microscopic polyangiitis a pilot study in 11 patients with renal involvement. J Ame Soc of Nephrol. 1999 Sep 1;10(9):1965-71.

5. European Mycophenolate Mofetil Cooperative Study Group. Placebo-controlled study of mycophenolate mofetil combined with cyclosporin and corticosteroids for prevention of acute rejection. Lancet 1995;345:1321.

6. Nowak I, Shaw LM. Effect of mycophenolic acid glucuronide on inosine monophosphate dehydrogenase activity. Ther Drug Monit. 1997;19:358.

7. Behrend M. Adverse gastrointestinal effects of mycophenolate mofetil: aetiology, incidence and management. Drug Saf. 2001;24:645-63. (PMID: 11522119).

8. Khanna D, Hays RD, Maranian P, Seibold JR, Impens A, Mayes MD, et al. Reliability and validity of the University of California, Los Angeles Scleroderma Clinical Trial Consortium Gastrointestinal Tract Instrument. Arthritis Rheum. 2009;61:1257-63.

9. Zeher M, Doria A, Lan J, Aroca G, Jayne D, Boletis I. et al. Efficacy and safety of enteric-coated mycophenolate sodium in combination with two glucocorticoid regimens for the treatment of active lupus nephritis. Lupus. 2011;20:1484-93.

10. Houssiau FA, D'Cruz D, Sangle S, Remy P, Vasconcelos C, Petrovic R, et al. Azathioprine versus mycophenolate mofetil for long-term immunosuppression in lupus nephritis: results from the MAINTAIN Nephritis Trial. Ann Rheum Dis 2010;69:2083-9.

11. Dooley MA, Jayne D, Ginzler EM, Isenberg D, Olsen NJ, Wofsy D, et al. Mycophenolate versus azathioprine as maintenance therapy for lupus nephritis. N Engl J Med. 2011;365:1886-95.

12. Mendoza FA, Nagle SJ, Lee JB, Jimenez SA. A prospective observational study of mycophenolate mofetil treatment in progressive diffuse cutaneous systemic sclerosis of recent onset. J Rheumatol. 2012;39:1241-7.

13. Derk CT, Grace E, Shenin M, Naik M, Schulz S, Xiong $\mathrm{W}$, et al. A prospective open-label study of 
mycophenolate mofetil for the treatment of diffuse systemic sclerosis. Rheumatology. 2009;48:1595-9.

14. Stratton RJ, Wilson H, Black CM. Pilot study of antithymocyte globulin plus mycophenolate mofetil in recent onset diffuse scleroderma. Rheumatology (Oxford). 2001;40:84-8.
Cite this article as: Das S, Padhan P. A study on the safety and tolerability of mycophenolate mofetil in patients with connective tissue disease. Int J Basic Clin Pharmacol 2018;7:2169-72. 